\title{
BLOOD CULTURE AS A PARAMETER OF TREATMENT EFFECTIVENESS IN EXPERIMENTAL HISTOPLASMOSIS OF THE HAMSTER
}

\author{
J. FINQUELIEVICH, M.R. ELIAS COSTA, C. IOVANNITTI \& R. NEGRONI
}

\begin{abstract}
SUMMARY
The aim of this study was to determine the value of blood culture as a parameter of treatment effectiveness in experimental histoplasmosis. A total of thirty five hamsters, weighing approximately $120 \mathrm{~g}$, were inoculated intracardiacly with $0.1 \mathrm{ml}$ of a suspension containing $4 \times 10^{7} \mathrm{cell} / \mathrm{s} / \mathrm{ml}$ of the yeast phase of $H$. capsulatum. Treatments were started one week after the infection and lasted for 3 weeks. The azoles, (itraconazole, saperconazole and fluconazole) were administered once a day by gavage, at a dose of $8 \mathrm{mg} / \mathrm{kg}$; Amphotericin B was given intraperitonealy every other day at a dose of $6 \mathrm{mg} /$ $\mathrm{kg}$. Blood samples $(1 \mathrm{ml})$ were obtained by heart punction from the 4th day after infection and were seeded in Sabouraud honey-agar and BHI-agar. The hamsters that survived were killed one week after treatment completion and the following criteria were considered for treatment evaluation: 1) rate of spontaneous death, at the end of the experience; 2) microscopic examination of Giemsa smears from liver and spleen and 3 ) determination of CFU in spleen cultures. Amphotericin B was the most effective drug, with negative blood cultures at day 20 , negative spleen cultures in all cases and all the animals survived until the end of the study. Fluconazole was the less effective drug, blood cultures were positive during the whole experience, spleen cultures showed a similar average of CFU when compared with the control animals and $42.8 \%$ of these animals died.

Saperconazole and itraconazole showed a similar activity, with survival of all hamsters and negative blood cultures at 23 and 26 days respectively. Blood culture seems to be valuable parameter for treatments' evaluation in experimental histoplasmosis of the hamster.
\end{abstract}

KEYWORDS: Histoplasmosis; Blood culture; Experimental model: Azoles; Amphotericin B; Treatment.

\section{INTRODUCTION}

In previous studies we showed that the intracardiac inoculation of the yeast phase of Histoplasma capsulatum determines a subacute, disseminated and fatal disease ?. This experimental model was useful for the evaluation of antifungal drugs ${ }^{5.6}$. The parameters which are usually taken into account for assessment of antifungal effectiveness are the rate of spontaneous death, the results of microscopic studies of liver and spleen and the number of colony forming units (CFU) in spleen cultures 5.6. Triazoles and amphotericin B are often used in the treatment of disseminated histoplasmosis 8. 2.10.12. Saperconazole is a new triazole which proved to be very active against Histoplasma capsulatum". 
In a previous study we observed a persistent fungemia in this experimental histoplasmosis 4.

The aim of this study was to determine if blood culture could be an effective parameter for treatment evaluation using this experimental model.

\section{MATERIAL AND METHODS}

A total of 35 hamsters (Mesocricetus auratus) of both sexes, of approximately $120 \mathrm{~g}$ of body weight were used. All animals were bred at our Mycology Center.

Varela strain of Histoplasma capsulatum, from cultures collection at this Mycology Center was used. The yeast-phase was maintained by weekly subcultures in $2 \%$ dextrose broth-agar, incubated at $37^{\circ} \mathrm{C}$.

\section{Inoculation technique:}

Hamsters were anes-thetized with ethylic ether and inoculated by intra-cardiac route with $0.1 \mathrm{ml}$ of a suspension containing $4 \times 10^{7}$ yeast cell $/ \mathrm{ml}$ of isotonic saline solution. The animals were divided into 5 groups of 7 hamsters each. Four groups were treated with amphotericin B, fluconazole, itraconazole and saperconazole, respectively and the remaining group received only the drugs vehicle and was considered as control.

\section{Treatment schedules:}

Itraconazole, fluconazole and saperconazole were suspended in distilled water with $0.2 \%$ agar and $5 \%$ dextrose, up to a final concentration of $10 \mathrm{mg} / \mathrm{ml}$. All the azoles compounds were administered once a day by gavage at a daily dose of $8 \mathrm{mg} / \mathrm{kg}$.

Amphotericin B was suspended in distilled water and was given intraperitoneally at a dose of $6 \mathrm{mg} / \mathrm{kg}$ every other day.

All the treatments were started 7 days after infection and lasted for 3 weeks.

\section{Evaluation criteria:}

One $\mathrm{ml}$ of blood was obtained from all the animals by heart puncture at day 4 post-infection. Blood samples for one hamster of each group were taken every day from the beginning of treatments up to the end of the experience. These blood samples were cultivated in Petri dishes containing Sabouraud honey-agar ( $40 \mathrm{~g}$ honey, $10 \mathrm{~g}$ peptone, $5 \mathrm{~g}$ yeast extract, $20 \mathrm{~g}$ agar, $1000 \mathrm{ml}$ distilled water) and brain-heart infusion agar (Difco) and were incubated at $28^{\circ} \mathrm{C}$ or $37^{\circ} \mathrm{C}$, respectively during 20 days. Colonies were identified by microscopic examination.

All hamsters were killed one week after treatment completion and were subsequently necropsied. The following evaluations were carried out: 1) microscopic examination of Giemsa smears searching for $H$. capsulatum in liver and spleen; 2) determination of CFU's in spleen; 3) massive seeding of an homogeneous suspension of the spleen in Sabouraud honey-agar $(0.2 \mathrm{ml}$ of a suspension containing $100 \mathrm{mg}$ of spleen per $\mathrm{ml}$ of distilled water).

Spontaneous deaths of hamsters that occurred during the experience were also recorded.

\section{RESULTS}

A persistent fungemia was detected in all the animals, from day 4 after infection which lasted up to the end of the experience both in the control and in the fluconazole groups of hamsters. Blood cultures turned negative in the animals treated with amphotericin $B$, saperconazole and itraconazole at days 20,23 and 26 after infection. Spontaneous deaths were registered in the control animals and in the hamsters treated with fluconazole. The results of the necropsies determinations are summarized in Table 1.

\section{DISCUSSION AND CONCLUSIONS}

This study shows as already reported, that this experimental model is very useful for evaluation of antifungal drugs in disseminated histoplasmosis. Spleen involvement has been seen in all cases, while other organs are also regularly involved.

Blood cultures are a very important diagnostic method in histoplasmosis associated to AIDS, as shown in previous studies ${ }^{1.2,10}$. In this animal model persistent fungemia was seen in the control hamsters as well as in those treated with fluconazole. Blood culture turned negative with all the other antifungal drugs evaluated. The earliest negativizations were obtained with amphotericin B while itraconazole was the last drug to obtain this result.

The results observed in this study seem to show that blood cultures negativization correlates well with the other parameters usually taken into account for therapeutical evaluation. 
FINQUELIEVICH, J.; ELÍAS COSTA, M.R.; IOVANNITTI, C. \& NEGRONI, R. - Blood culture as a parameter of treatment effectiveness in experimental histoplasmosis of the hamster. Rev. Inst. Med. trop. S. Paulo, 37(2): 99-102, 1995.

TABLE 1

Results of the studies in the experimental histoplasmosis in hansters

\begin{tabular}{|c|c|c|c|c|c|}
\hline \multirow[t]{3}{*}{ Animals } & \multirow{2}{*}{\multicolumn{2}{|c|}{$\begin{array}{c}\text { Microscopic } \\
\% \text { of positivity }\end{array}$}} & \multicolumn{2}{|c|}{ Spleen Cultures } & \multirow{3}{*}{$\begin{array}{c}\text { Percent of } \\
\text { Spontaneous Death }\end{array}$} \\
\hline & & & $\mathrm{CFU} / \mathrm{g}$ & Massive & \\
\hline & Spleen & Liver & the group & positivity & \\
\hline Control & 100 & 100 & $2 \times 10^{x}$ & 100 & 57.1 \\
\hline Fluco & 100 & 100 & $2 \times 10^{8}$ & 100 & 42.8 \\
\hline Itra & 0 & 50 & $1.25 \times 10^{6}$ & 75 & 0 \\
\hline Sap & 42 & 57 & $1.57 \times 10^{6}$ & 57.1 & 0 \\
\hline Amb & 16 & 0 & 0 & 0 & 0 \\
\hline
\end{tabular}

References: C.F.U.: colony forming units; Fluco: fluconazole; Itra: itraconazole; Sap: saperconazole; Amb: amphotericin B.

Saperconazole a new triazole was effective in the treatment of this experimental model of disseminated histoplasmosis, it was slightly superior than itraconazole, confirming the results of previous papers ${ }^{11}$.

Itraconazole is a triazolic compound very active against $H$. capsulatum both "in vivo" and "in vitro". Although it is less effective than amphotericin B in the experimental histoplasmosis of the hamster. Both drugs have shown similar results in the treatment of patients with histoplasmosis and AIDS 9.10.

Fluconazole at the dose used in this study, did not modify the parameters evaluated and was not able to negativize blood cultures, but the spontaneous death range seen with this drug was lower than that of control animals. Fluconazole did not seem to be very effective in the treatment of histoplasmosis confirming the results obtained in clinical investigations 6 .

\section{RESUMEN}

\section{Hemocultivos como parametro de la eficacia del tratamiento de la histoplasmosis experimental en hamster}

El propósito de esta investigación fue determinar el valor de los hemocultivos para juzgar la eficacia de los tratamientos en la histoplasmosis experimental. Treinta y cinco hamsters fueron inoculados por via intracardíaca con $0.1 \mathrm{ml}$ de una suspensión de la fase levaduriforme del $H$. capsulatum equivalente a $4 \times 10^{7}$ células $/ \mathrm{ml}$. Los tratamientos comenzaron 1 semana después de la infección y se mantuvieron durante 3 semanas. Los compuestos azólicos, itraconazol, saperconazol y fluconazol se administraron por gastroclisis, una vez al día, a razón de $8 \mathrm{mg} / \mathrm{kg}$ de peso; la anfotericina $\mathrm{B}$ fue aplicada por via intraperitoneal día por medio, en dosis de $6 \mathrm{mg} / \mathrm{kg}$. Se obtuvieron muestras de sangre para hemocultivo $(1 \mathrm{ml})$ a partir del $4^{\circ}$ día post-infección y se sembraron placas de agar-miel de Sabouraud y agar infusión de cerebro y corazón.

Los animales que sobrevivieron fueron autopsiados y se tomaron en consideración los siguientes parámetros: 1) tasa de muertes espontáneas al finalizar la experiencia; 2) resultados de los exámenes microscópicos de extendidos de hígado y bazo teñidos com Giemsa y; 3) UFC en cultivos de bazo.

La anfotericina $\mathrm{B}$ fue la droga más eficaz, los hemocultivos de los animales tratados fueron negativos a partir del $20^{\circ}$ dia de tratamiento, se negativizaron los cultivos de bazo y la totalidad de los hamsters sobrevivió. El menos eficaz fue el fluconazol que no modificó los resultados de los hemocultivos y los cultivos esplénicos y se registró el $42.8 \%$ de muertes espontáneas durante el estudio. Saperconazol e itraconazol exhibieron una eficacia similar, no se observaron muertes en los animales tratados y los hemocultivos se negativizaron a los 23 y 26 dias de tratamiento respectivamente.

Los hemocultivos resultaron ser útiles como criterio para evaluar la eficacia terapéutica de las drogas antifúngicas en este modelo experimental de histoplasmosis.

\section{REFERENCES}

1. ARECHAVALA, A.; ROBLES, A.M.; NEGRONI, R.; BIANCHI, M. \& TABORDA, A. - Valor de los métodos directos e indirectos de diagnóstico en las micosis sistémicas asociadas al SIDA. Rev. Inst. Med. trop. S. Paulo, 35: 163-169, 1993. 
FINQUELIEVICH, J.; ELIAS COSTA, M.R.; IOVANNITTI, C. \& NEGRONI, R. - Blood cullure as a parameter of treatment effectiveness in experimental histoplasmosis of the hamster. Rev. Inst. Med. trop. S. Paulo, 37(2): 99-102, 1995.

2. BIANCHI, M. \& NEGRONI, R. - Estudio comparativo de dos sistemas de hemocultivos en micosis sistémicas asociadas al SIDA. Rev. argent. Derm., 74: 1-4, 1993.

3. DIAZ, M.; NEGRONI, R.: MONTERO-GEI, F. et al. - Pan American 5 year study of fluconazole therapy for deep mycoses in immunocompetent lrost. Clin. infect. Dis., 14 (suppl. 1): S68-S76, 1992.

4. FINQUELIEVICH, J.L. - Hemocultivos para el control de la evolución de la histoplasmosis experimental del hamster. St modificación por el trataniento con itraconazol. In: CONGRESO ARGENTINO DE MICOLOGIA, 4., Huerta Grande, Córdoba. 1989.

5. FINQUELIEVICH, J.L.; NEGRONI, R.: IOVANNITTI, C. \& BAVA, J. - Treatment of disseminated histoplasmosis in hamsters. Mycopathologia (Den Haag), 105: 75-78, 1989.

6. FINQUELIEVICH, J.L.; ELIAS COSTA, M.R.I. de.; NEGRONI, R. et al. - Compuestos triazólicos en el tratamiento de la histoplasmosis diseminada experimental del hanster. Rev. argent. Micol., 13(3): $5-11,1990$.

7. IOVANNITTI, C.; NEGRONI, R.; FINQUELIEVICH,J.L. \& BAVA, J. - Histoplasmosis diseminada experimental del hamster. Rev. argent. Micol., 11(1): 11-17, 1988.
8. JOHNSON, P.; KHARDORI, N.; NAFFOR, A. et al. - Progressive disseminated histoplasmosis in patient with acquired immunodeficiency syndrome. Amer. J. Med., 81: 974-978, 1988.

9. NEGRONI, R.; TABORDA, A.; ROBLES, A.M. \& ARECHAVALA, A. - litaconazole in the treatment of histoplasmosis associated with AIDS. Mykosen, 35: 281-287, 1992.

10. NEGRONI, R.; ROBLES, A.M.; ARECHAVALA, A. \& TABORDA, A. - Histoplasmosis en pacientes con SIDA, su evolución y 1ratamiento. Rev. argent. Micol., 14(3): 5-12, 1991.

11. ODDS, F. - Antifungal activity of saperconazole ( $\mathrm{r} 66905$ ) "in vitro" J. Antimicrob. Chemother., 24: 533-537, 1989.

12. SAROSI, G. \& DAVIES, S. - Clinical manifestations and management of histoplasmosis in the compromised patient. In: WARNOCK, D.W. \& RICHARDSON, M.D. Fingral infection in the compromised patient. New York, Jolnn Wiley \& Sons, 1982. p. 187-198.

Recebido para publicação em 19/07/1994 Aceito para publicação em 18/10/1994 